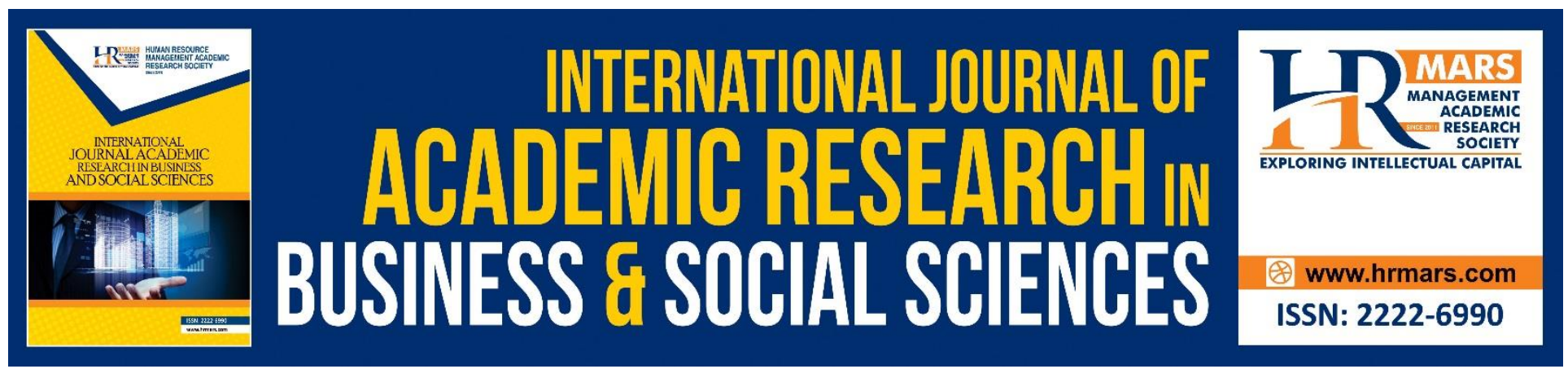

\title{
Conceptualization of Strategy and Implementation of Islamic School Climate in Religious Secondary Schools
}

Raihan binti Mohd Arifin, Kamarul Shukri bin Mat Teh

To Link this Article: http://dx.doi.org/10.6007/IJARBSS/v8-i10/4739 DOI: $10.6007 /$ IJARBSS/v8-i10/4739

Received: 15 Sept 2018, Revised: 21 Oct 2018, Accepted: 29 Oct 2018

Published Online: 31 October 2018

In-Text Citation: (Arifin \& Teh, 2018)

To Cite this Article: Arifin, R. binti M., \& Teh, K. S. bin M. (2018). Conceptualization of Strategy and Implementation of Islamic School Climate in Religious Secondary Schools. International Journal of Academic Research in Business and Social Sciences, 8(10), 340-351.

Copyright: (C) 2018 The Author(s)

Published by Human Resource Management Academic Research Society (www.hrmars.com) This article is published under the Creative Commons Attribution (CC BY 4.0) license. Anyone may reproduce, distribute, translate and create derivative works of this article (for both commercial and non-commercial purposes), subject to full attribution to the original publication and authors. The full terms of this license may be seen at: http://creativecommons.org/licences/by/4.0/legalcode

Vol. 8, No. 10, 2018, Pg. 340 - 351

Full Terms \& Conditions of access and use can be found at http://hrmars.com/index.php/pages/detail/publication-ethics 


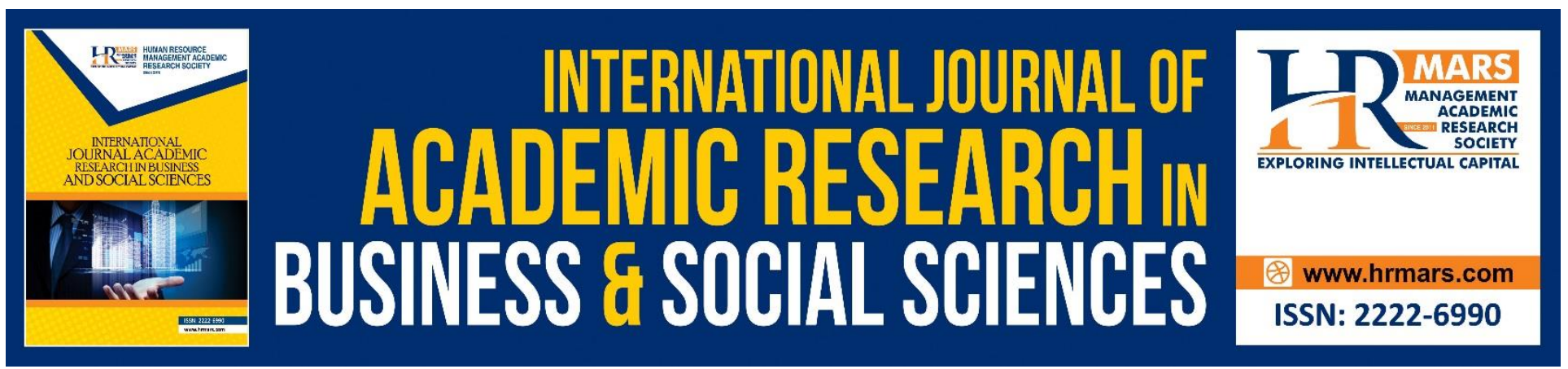

\title{
Conceptualization of Strategy and Implementation of Islamic School Climate in Religious Secondary Schools
}

\author{
Raihan binti Mohd Arifin ${ }^{1}$, Kamarul Shukri bin Mat Teh² \\ ${ }^{1}$ Phd Candidate, Universiti Sultan Zainal Abidin (UniSZA), Kampus Gong Badak. Kuala 21300 Kuala \\ Nerus, Terengganu, Malaysia, \\ ${ }^{2}$ Lecturer, Faculty of Islamic Contemporary Studies, Universiti Sultan Zainal Abidin (UniSZA)
}

\begin{abstract}
The formation of a student's identity is closely related to climate change in schools. Good climate development in schools begins with a robust strategy and implementation plan. Both of these variables are an important foundation in forming an Islamic school climate in Religious Secondary Schools. Hence, a clear of Islamic school climate concept should be highlighted in order to examine all strategies and implementation in order to produce balanced students from both academic and personality aspects. This paper aims to examine how the strategies and implementation of Islamic school climate at Religious Secondary Schools play a role in shaping the character and identity of the students with their own distinctive reference. Thus, a literature review focusing on the observation of previous studies has been done. As a result, a conceptual concept of Islamic school climate implementation is based on a combination of positivism and Islamic perspective. The implication of this study is expected to be used to create an Islamic school climate in the school community to improve the quality of the students in the Religious Secondary School and can be used as a guide to Islamic school culture.
\end{abstract}

Keywords: Islamic School Climate, Strategy, Implementation, Religious Secondary School.

\section{Introduction}

If we look at the world nowadays, science and technology are growing rapidly. The social problem is also increasing along with the current development. Most parents are already aware of sending children to religious schools as one of the safe ways to get a perfect and balanced education both academically and emotionally. Indirectly it provides the best education for their children. However, what is alarming is that the environment in religious high schools is expected to provide the perfect education to the students in shaping their identity. Therefore, a study to identify the Islamic school 
INTERNATIONAL JOURNAL OF ACADEMIC RESEARCH IN BUSINESS AND SOCIAL SCIENCES Vol. 8, No. 10, Oct. 2018, E-ISSN: 2222-6990 @ 2018 HRMARS

climate in religious schools should be looked at in more detail. This is closely related to the strategy and implementation plan implemented by the school in forming an Islamic school climate.

Among the strategic plans presented in Ibn Khaldun's (1993) Preamble book are ansyitah and practical. While the implementation aspect involves the leadership of the school community and also the relationship with the community at school. Both aspects of the strategy and implementation are very important and interconnected in forming an Islamic school climate at school. Strategy and implementation are also two variables that are rarely studied simultaneously to see the influence of both on student enrolment in religious high schools. If we only looks at one of the academic items (MacNeil, Prater, \& Busch 2009; Salasiah Hanin, Ermy Azziaty, Rosmawati 2012) or personality (Lukman 2014: Norhisham 2015; Zakaria, Munawar 2012) and not to mention, to view the whole aspects consistent with the requirement by National Education Philosophy.

School climate topics have been widely studied to investigate the impact that the school environment has on the student's learning achievements and behaviours (Dellar 1999; Gu Saw Lan 2014; Ming-Te Wang \& Degol 2016). There are over 100 references regarding school climate that have been studied by Western researchers. But when examined in more detail, studies related to the school climate are still much less prevalent in the Islamic school climate or also known as the Islamic environment among religious school students.

However, most empirical studies of the school climate are focused solely on academic achievement (MacNeil, Prater \& Busch 2009; Maxwell \& Ross Thomas 1991). There are not many studies that discuss the form of strategies that need to be done simultaneously and discuss in detail the necessary actions /activities. Initially, the school climate has no definite guidelines for each school. It is actually up to the principals and administrators to build and make plans for their respective school climate in accordance with the goals and National Education Philosophy.

In addition, there are also Western studies that have discussed the relevance of school climate with students' academic achievement from Western practices (Bear, Yang, Pell, \& Gaskins 2014; Cohen, Mccabe, \& Michelli 2009; MacNeil et al., 2009). However, studies that use the Islamic approach to the form of appreciation and practice of Islamic spiritual activities linked to the strategies adopted and the way in which systematic and systematic school climate management are being implemented and looking at the overall aspect of forming student immunities is still lacking. Hence, this study needs to be carried out in more detail and in depth with a mix of Islamic and Western concepts to obtain a complete and clear guideline for use in accordance with climate in religious secondary schools.

\section{Definition Of Islamic School Climate}

Western researchers had provided several definition of 'school climate'. Among these definitions are climate is the attitude, belief, value and motivation of an individual in a particular organization (Litwin \& Stringer 1968); the personality of an organization (Halpin 1967); the atmosphere of the school environment that affects the pattern of individual and group behaviours (Spencer, Pelote \& Seymour 
INTERNATIONAL JOURNAL OF ACADEMIC RESEARCH IN BUSINESS AND SOCIAL SCIENCES Vol. 8, No. 10, Oct. 2018, E-ISSN: 2222-6990 ㄷ 2018 HRMARS

1998); student perceptions of events, practices, procedures and behaviours in the environment (Schneider, Wheeler \& Cox 1992; Garret 1990).

Islamic school climate means the Islamic environment or the religious atmosphere that exists in the school environment. It involves the practice and habits of an individual or local community and practicing the teachings of Islam in the daily life of the community, especially in appreciation of noble moral character with a clean, cheerful and pleasant physical atmosphere of all its citizens (Mahi Din 1998: Norhisham \& Azmil 2017; Raihan \& Abdul Hakim 2015)

The climate in each school is different. It depends on various aspects such as communication, leadership, relationships between school community members, teaching strategies used, activities and appreciation and practice applied to students. Based on the above definition, it can be concluded that Climate is the nature, condition or atmosphere of a school that is formed as a result of the interaction between its citizens. Indirectly it gives affects either positive or negative to entire population.

\section{Strategy In Implementing Islamic School Climate In School}

Strategy is an overall approach to implementation. Based on Ibn Khaldun's (1993) view in the book of Mukadimah, a good environmental strategy is dependent on the activities undertaken as well as the practice that becomes its practice in daily routine.

\section{Strategy of Ansyitah/ Activities}

Ansyitah plays an important role in shaping the learning environment in schools so that students feel more comfortable and confident. Ansyitah is a beneficial activity made by students. The activities or programs held for these students can contribute to social development and give a positive influence to the students' personality and spirituality. These activities are carried out routinely, weekly, and monthly so as to nurture skills among students although this does not count as a manhaj.

According to Ibn Khaldun (1993) activity or program is a necessity to nurture the skills among students. Activities that are conducted can form self-reliance, collaborate with others, capable of acting and addressing the life problems faced. The result of the activity will be able to produce noble and capable students. In addition, Paul B. Horton (1964) also explains that activities or activities in the school that are always met by social interactions, communication and collaboration among members will help the formation of students' personality in a school organization.

The study conducted by Ab. Halim Tamuri (2003) also supports the importance of carrying out religious activities. She finds that many students agree with the school surau activities that have succeeded in establishing the loyalty of fellow students. This means that the activities implemented have created a positive social interaction environment among students. The study by Norhisyam (2015) also found that religious activities or programs have indeed influenced the students' morality in religious schools. This shows that the formation of student character is more influenced by a positive school environment. The involvement of students in religious activities conducted in schools 
will provide the filling and enrichment of souls with deeper religious values as well as enhancing the understanding of Islam more clearly.

It is clear that ansyitah or activity plays an important role in creating an Islamic school climate in school. Every activity to be carried out needs to be carefully planned so that the planned goals are achieved and can produce a good result for students in forming a noble character.

\section{Practical Strategy / Actions}

The practical strategy in this study means every action practiced by the students. Amali is a behavior, behavior or act done by the students so that it becomes a habit in itself and affects the formation of the student's morality. The act or practice does not matter whether it is in the form of compulsory worship and circumcision as well as matters relating to commendable acts and away from prohibited things. The Qur'an mentions that knowledge gained through the process of ta'lim should be implemented in the form of practice. The practice carried out through the teaching and learning process, will be more mastered and appreciated until it develops a habit in itself (Janzarli 1991). The principle of practice is an educational process that is spearheaded by the Prophet Muhammad SAW:

$$
\text { مَ }
$$

"Whoever practices what he knows, then God will give him knowledge that he does not know".

This verse explains that God loves if we can practice knowledge learned mainly based on what has been mentioned in the Qur'an. Therefore, practical strategies are especially emphasized in Ibn Khaldun's theory (1993) because the behaviour of the surrounding environment will affect the formation of students' morals.

Besides the actions, events that occur around the students will also affect their practice. If they are in a good situation, the students will also emulate such good practices and vice versa. However, the process of proclaiming good morals requires continuous effort as well as making practical training in order to familiarize yourself with the virtuous qualities and avoid all the good qualities (Ghazali 1997).

Hence, self-contempt can be recognized by always reflecting on and reflecting on selfreflection of what has been done throughout the day as well as practicing daily practices such as remembrance, reading the Qur'an and understanding its meaning, qiamullail and so on. These practices are one of the ways to achieve good morals. All acts and behaviors in Islam are made as daily practices according to the specific procedures that every one of them should obey. This procedure is not intended to disturb Muslims but as a guarantee of the well-being of the world and the hereafter.

The education process takes place by familiarizing children to create good values and norms over a long period of time so they are used to doing these good deeds. Perseverance in exercising 
INTERNATIONAL JOURNAL OF ACADEMIC RESEARCH IN BUSINESS AND SOCIAL SCIENCES

Vol. 8, No. 10, Oct. 2018, E-ISSN: 2222-6990 C 2018 HRMARS

the practice of religion will also contribute to the improvement of morality as an easy example is the practice of prayer as the word of Allah S.W.T in surah (al-Ankabut 29: 45);

Which means: Read and follow what is revealed to you from the Quran and establish the prayer (diligently); verily, the Prayer prevents from the abomination of evil and the remembrance of Allah is greater. And Allah knows what you do.

The views of the above educational leaders proved that a practice (deed) in society could affect the life of its youth ie the students. Hence, in the context of education especially in schools every good deed done by its citizens will be the following which leads to the appreciation and practice of noble character as required by the Shari'a.

\section{Implementation In Islamic School Climate In The School}

Implementation is an effort undertaken in order to create an Islamic school climate in religious secondary schools. This implementation is planned or formulated regularly to achieve the stated goals. Implementation of Islamic school climate not only focuses on the activities organized by the school such as the physical, cultural and daily environment of students and the school community, but also look at leadership, as well as relationships with the respective school communities that cover all aspects of life.

\section{Leadership}

Schools are social institutions (Getzels \& Guba, 1970). It is an organization consisting of students, teachers, administrators, and various types of service personnel. Each member of this group has different character and way of thinking. If the relationship between these organizations can be understood and accepted in general, school climate organizations will function effectively (Campell, Corbally \& Nystrand 1983). School is also a hierarchical organization. The Ministry of Education Malaysia (KPM) is the highest hierarchy, followed by the State Education Department (JPN), the District Education Office (PPD), principals, teachers and students.

This relationship hierarchy serves as the basis for allocating and integrating staff roles in achieving school vision and mission. Operationally, this educational organization is a process of interaction with each other in the school. Each educational organization has a climate and influence of different behaviours of each school (Sergiovanni \& Starratt, 1988). Therefore, the effectiveness of the school begins with leadership, good school climate and effective communication (Kelly \& Robert 2005).

Leadership is closely linked to the Islamic school climate in school. Strong and clear leadership roles strongly influence the behaviour of its citizens in terms of clear goals, strategic planning and implementation, as well as evaluating matters. Leadership is largely related to programs or activities undertaken at schools, teachers' responsibilities towards students, as well as relationships between school communities. Each school has different visions and missions depending on the school's leadership. The main role of the leader is determining the mission, vision and inspiration and goals 
to be achieved. According to Everards and Morris (1990), James and Balasandran (2012), studies in schools are effective in terms of job performance indicating that the school has a clearly defined mission. Therefore, the mission and vision of the school should be clear and lead to things that are closely related to the teaching and learning of its students to determine the purpose and holdings that guide the aspects of the organization's actions and activities. Therefore, the elements of leadership, good curriculum learning and community attitude indirectly determine the academic or student achievement.

\section{Community Relations}

Relationship with the community can be defined as the quality of relationships between school members (teachers, students, administrators, and staff) who have influence on student behaviour and achievement. The relationship between students and teachers affects their relationship in class, self-esteem, and grade. The climate aspect of the school climate refers to the quality of relationships within the school. It also includes school networks, respecting each other, and sharing with other members of the community (Ming \& Degol 2016).

The formation of school climate emphasizes the behaviour of the community around. Ibn Khaldun (1993) emphasizes the practice of community behaviours because the behaviour or actions of the society will affect the formation of students' morals. Events that occur around the student will affect their behavioural practices. If they are in a good situation, then other students will also emulate such good practices and that is the opposite. In conclusion, the community is an individual environment that resides in one place and interacts with each other which involves the relationship between humans, which enables the occurrence of behavioural change. This environment involves the elements of cooperation, help-sharing, sharing of ideas, and feelings of mutual affection.

\section{Methodology}

This study uses a qualitative approach in collecting data related to research topics. Content analysis is used to study relevant sources that represent the views of Islam. It is based on information from the Quran, the Prophet's hadith and the views of Islamic and Western scholars.

\section{School Climate Concept From Positivism Perspective}

Western researchers over five decades have studied and given different definitions regarding school climate. Over the past few years, researchers and educators have discussed a lot about school climate and their impact on students. Halpin and Croft (1963) who are pioneers in school climate studies say the school climate reflects the personality of an individual himself. However, according to Cohen et al. (2009) view of school climate refers to the quality and character of school life, which usually includes norms, values, interpersonal relationships, teaching practices that take place in schools and organizational structures. Whereas Howard, Howell and Brainard (1987) define school climate as a learning environment, including one's feelings about school. Freiberg and Stein (1999) have also defined school climate as the heart and soul of the school. 
Furthermore, Hoy and Miskel (2001) also support the findings and have defined the climate as a result of the actions of certain groups in the school system such as students, teachers and administrators who work together to balance the needs of individuals and organizations in social systems. It encompasses aspects such as sharing values, beliefs and social dimensions. Sergiovani (1988) defines the climate as a feature that illustrates a school and distinguishes it from other schools. It affects the behavior, nature or atmosphere of a school as a result of interaction and the state of human relationships and activities and practices undertaken within the school (Bronfenbrenner 1994).

Therefore, the school climate can be summarized as unique to members of the organization and visitors who visit the school, including the behavior of its citizens. Conclusion in this study, the term 'school climate' refers to life in the school environment, which includes everything that happens in the school area. As school climate plays an important role in determining the performance of students, teachers and schools, it is a topic that specialists need to pay attention to.

\section{The Concept of Islamic School Climate From an Islamic Perspective}

Education is the process of cultivating and educating something in the human life towards a better. This process of engagement involves methods and systems which refer to the process being presented gradually. This process relates to the content of the desired fertilizer in the human being (Syed Muhammad Naquib al-Attas, 1977). Climate talks and discussions have been taking place for a long time. These discussions have not only occurred among Western scholars, but Islam and Muslim scholars have long been emphasizing climate.

In the teachings of Islam, climate is very much emphasized. Various life concepts and societies are introduced such as united life, love, talk, talk, mutual cooperation and so on. All this is considered as worship and when done sincerely will receive a reward in the sight of Allah. Ibn Khaldun (1993) strongly emphasizes the role of climate for good moral character. According to Ibn Khaldun, good climate is necessary to produce good morals and good morals need to be born of itself based on their observations on climate factors that can affect the habits of human life. This is because humans differ in the climate of which they are. Whoever is in the climate that helps him to goodness, then he is more likely to be good and vice versa. In fact, Imam al-Ghazali also emphasizes the climatic factors for establishing noble syakhsiyyah in a person through observation and intercourse.

According to al-Ghazali, the human nature is imitative in which one can obtain both the good and the bad from the other's condition. If a person associates with a righteous person within a certain period of time, he will gain in himself a favour from the person and unknowingly. Among the things that Islam strives for is a climate or a wonderful atmosphere. It is mentioned in Arabic as al-climate al-solehah. The existence of a righteous or pious environment will affect the formation of the soul and the inhabitants of the occupation. Humans when living in an atmosphere, it usually will affect them. If a wise person lives among the wise, then a little bit of speech and a wise and good opinion will happen to him. 
Syed Muhammad Naquib al-Attas (1977) mentions that Ibn Khaldun's Preamble's examines the "physical environment in which humans live to understand how they affect him in their physical characteristics." He explains the differences between different people, whether nomadic or permanent people, including their custom and institutions, in terms of habitat, climate, land, food, and different ways in which they are required to meet the needs of life. The conclusion of the outcome of the view of the Islamic intellectuals explains how much the influence of climate in one's daily life in forming a Muslim identity based on Islamic principles. Climate is indeed a very important role in forming one's morals.

\section{Discussion and Conclusion}

The concept of Islamic school climate is formed as a result of a combination of all western and Islamic theories to obtain correspondence and the creation of a clear concept and to be followed by all walks of life. This concept is expected to be adopted by all types of schools in Malaysia. From the various definitions of the concept of school climate discussed above, it can be concluded that the school climate is what each individual school has to do which involves the internal factors of each individual including the relationship between the principal and the teacher, the teacher with the student and the support staff. All of these treatments illustrate how the characteristics of the school climate are formed effectively.

Hence, the combination of robust strategies and implementation in the formation of Islamic school climate in schools is able to determine a success or failure in a school. Based on the discussions, a school climate concept framework has emerged from a point of view of positivism and Islamic views. There is little in common from the perspective of Islamic and Western implementation strategies that can be applied globally. Nevertheless, the majority of Islamic and Western scholars conclude that a good Islamic school climate can shape the overall identity of the students in terms of academic achievement and character.

There are various advantages and disadvantages of strategies and implementations used in forming a balanced Islamic school climate. Therefore, the strategy and its implementation should be carefully planned and carried out more seriously by all parties, especially in religious schools, as religious schools are exemplary examples of regular secondary school students in every aspect of academic or personality.

It is important that the implementation of Islamic school climate in religious high schools be able to achieve the goals of religious school education in line with the Islamic Education Philosophy and succeeded in producing the world's brightest generation of Muslims and the hereafter. Hence a further study titled 'Strategic Assessment and Implementation of Islamic school climate in Schools' should be conducted to assess the climate in different religious secondary schools. Hopefully this study can contribute clear and concise literature to enable the improvement process to be continued and implemented from time to time. 
INTERNATIONAL JOURNAL OF ACADEMIC RESEARCH IN BUSINESS AND SOCIAL SCIENCES Vol. 8, No. 10, Oct. 2018, E-ISSN: 2222-6990 @ 2018 HRMARS

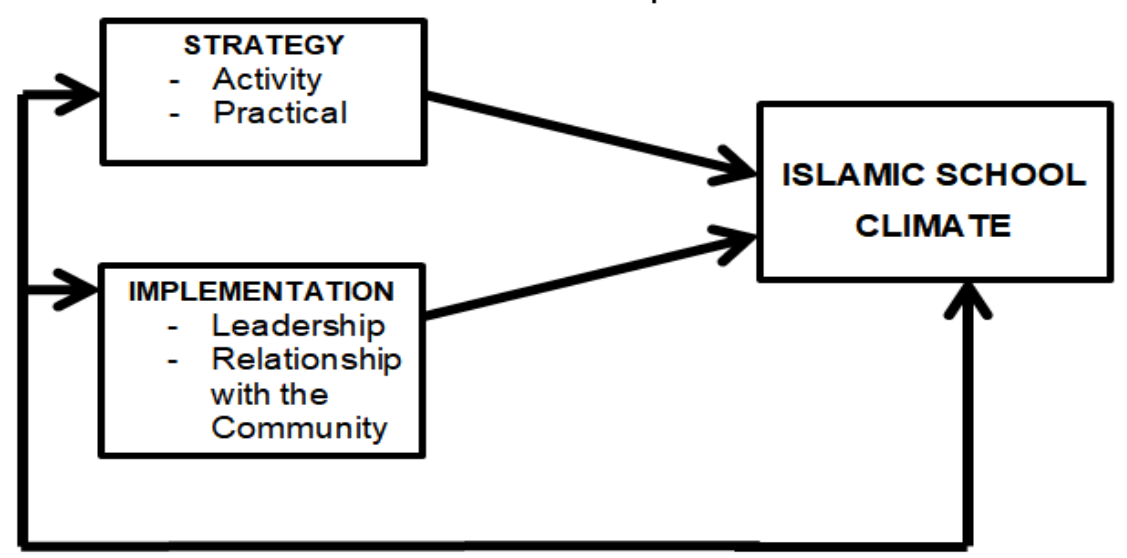

\section{Acknowledgement}

Thanks to Faculty of Islamic Contemporary Studies (FKI), University Sultan Zainal Abidin (UniSZA) for giving permission and cooperation to prepare this research. Special thanks to supervisor for comments and guidance to improve this article.

\section{Corresponding Author}

Raihan binti Mohd Arifin, Faculty of Islamic Contemporary Studies, University Sultan Zainal Abidin (UniSZA), Kampus Gong Badak, Kuala Terengganu. Email: raifad5566@gmail.com.

\section{References}

Al-Quran al-Karim

Al-Ghazali, A.H. M (n.d). Ihya Ulum Al Din (Jil.3). Dar al-Kutub al-Ilmiah, Beirut, Lubnan.

Ab. Halim Tamuri (2010). "Penilaian Pelajar-Pelajar Terhadap Amalan Pengajaran Guru Pendidikan Islam di Sekolah-Sekolah Menengah di Malaysia" dalam Persidangan Serantau Pendidikan Islam, 1- 12.

Bear, G. G., Yang, C., Pell, M., \& Gaskins, C. (2014). Validation of A Brief Measure of Teachers Perceptions of School Climate : Relations To Student Achievement and Suspensions. Learning Environments Research, 339-354.

Bronfenbrenner, U. (1994). Ecological Models of Human Devepment. International Encyclopedia of Education, 3(2). Oxford: Elsevier.

Campell, R. F., Corbally J. E., \& Nystrand R. O. (1983). Introduction to Educational Administration. USA.

Cohen, J., Mccabe, E. M., \& Michelli, N. M. (2009). School Climate: Research, Policy, Practice and Teacher Education. Teachers College Record, 111(1), 180-213.

Dellar, G. B. (1999). School Climate, School Improvement and Site- Based Management, (1963), 353-367.

Everard, K. \& Morris, G. (1990). Effective School Management. London: Paul Chapman Publishing. Freiberg, H. J. (1998). Introduction, in School Climate: Measuring, Improving and Sustaining Healthy Learning Environments. 1-11. Philadelphia, PA: Falmer Press. 
INTERNATIONAL JOURNAL OF ACADEMIC RESEARCH IN BUSINESS AND SOCIAL SCIENCES

Vol. 8, No. 10, Oct. 2018, E-ISSN: 2222-6990 @ 2018 HRMARS

Freiberg, J. H. \& Stein, T. A. (1999). Measuring, Improving and Sustaining Healthy Learning Environments. 11-29. Philadelphia, PA: Falmer Press.

Garret, B.(1990). Creating A Learning Organization. Cambridge: Director Books.

George J., \& Bishop L. (1971). Relationship of Organizational Structure and Teacher Personality Characteristics to Organizational Climate. Administrative Science Quarterly, 16, 467-476.

Getzels, J. W., \& Guba E. G. (1970). Social Behaviour and The Administrative Process, Selected Readings on General Supervision, London. The Macmillan Company.

Ghazali Darusalam. (1997). Dinamika Ilmu Akhlak Islamiah. Kuala Lumpur. Utusan Publications \& Distributors Sdn. Bhd.

Gu Saw Lan. (2014). The Relationship Between Instructional Leadership Behaviour, School Climate and Teacher Efficacy In Secondary Schools In Kedah. Tesis Phd.

Hall D. T., Bowen D. D.,Lewicki R. J., \& Hall F. S.(1982). Experiences in Management and Organizational Behavior. USA: John Wiley \& Sons.

Halpin, A. W., \& Croft D. B. (1963). Organizational climate of schools. Chicago: University of Chicago, Midwest Administration Center.

Halpin, A. W. (1967). Theory and Research In Administration. New York: Macmillan.

Howard, E. Howell. B \& Brainard. E. (1987) Handbook For Conducting School Climate Improvement Project. Indiana: The Phi Delta Kappa Educational Foundation.

Hoy W. K., Hofman J., Sabo D., \& Bliss J. (1996). The Organizational Climate of Middle Schools: The Development and Test of The OCDQ-RM. Journal of Educational Administration. 34(1), 41-59.

Hoy, W.K. \& Miskel, C.G. (2001). Educational Administration: Theory, Research and Practice, 6th Edition. Boston: McGraw-Hill.

Ibnu Khaldun, Abd Al-Rahman bin Muhammad Khaldun Al-Hadrami (2002). Mukadimah Ibnu Khaldun. Terj. Dewan Bahasa dan Pustaka. Kuala Lumpur : Dewan Bahasa dan Pustaka.

Ibnu khaldun, (1993) Muqaddimah Ibnu Khaldun. Terjemahan Dewan Bahasa dan Pustaka, Kuala Lumpur.

James, A. J. E., \& Balasandran, R. (2012). Kepimpinan Instruksional Satu Panduan Praktikal (Kedua.). Batu Caves: PTS Akademia.

Janzarli, R. S. (1991). Al-Usul al-Islamiah li al-tarbiah. Makkah: Umm al-Qura University Press.

Kelly \& Robert C. (2005). Relationships Between Measures of Leaderships and School Climate. Journal of School Research and Information, (1979), 1-7.

Litwin G., \& Stringer R. (1968). Motivation and Organizational Climate. Boston: Harvard Business School Research Press.

MacNeil, A. J., Prater, D. L., \& Busch, S. (2009). The Effects of School Culture and Climate on Student Achievement, 12, 73-84.

Sari, M. D. (1998). Iklim Dini di Sekolah. Jurnal Dakwah 1 (1): 33-47.

Maxwell, T. W., \& Ross Thomas, A. (1991). School Climate and School Culture. Journal of Educational Administration, 29(2).

Ming-TeWang, \& Degol, J. L. (2016). School Climate : A Review of The Construct, Measurement, and Impact on Student Outcomes. Educational Psychology Review. Educational Psychology Review.

Ramli, N. (2016). Prestasi Guru Pendidikan Islam Berasaskan Daya Kekuatan Dalaman ,Kepimpinan Pengetua dan Iklim Sekolah. Tesis PhD Universiti Malaya. 
INTERNATIONAL JOURNAL OF ACADEMIC RESEARCH IN BUSINESS AND SOCIAL SCIENCES

Vol. 8, No. 10, Oct. 2018, E-ISSN: 2222-6990 @ 2018 HRMARS

Norhisham, M. \& Hashim, A. (2017). Pelaksanaan Biah Solehah dan Kesan Terhadap Penghayatan Akhlak Pelajar Sekolah Menengah Kebangsaan Agama. Jurnal Teknikal dan Sains Sosial, 8(1), 25-43.

Paul, B. H., Chester, L. H. (1964). "Sociology", USA, McGraw-Hill Book.

Schneider, B., Wheeler, J.K., \& Cox, J.F. (1992). A Passion For Service: Using Content Analysis To Explicate Service Climate Themes. Journal of Applied Psychology 77, 705-716.

Sergiovanni T. S., \& Robert J. Starratt. (1988). Supervision: Human Perspectives. New York: Mc Graw Hill.

Spencer L. M., Pelote V., \& Seymour P. (1998). A Causal Model and Research Paradigm For Physicians As Leaders of Change. New Medicine, 2:57-64.

Warren, E. G. (1967), "The Spread of Ibnu Khaldun's Ideas on Climate and Culture", Journal of the History of Ideas, University of Pennsylvania Press, 28 (3): 415-422. 